\title{
POLITIK ISLAH: RE-NEGOSIASI ISLAH, KONFLIK, DAN KEKUASAAN DALAM NAHDLATUL WATHAN DI LOMBOK TIMUR
}

\author{
Saipul Hamdi \\ Program Studi Manajemen Lingkungan, Jurusan Manajemen Hutan \\ Politeknik Pertanian Negeri Samarinda, Kalimantan Timur \\ Email: hamdi_ugm@yahoo.com
}

\begin{abstract}
This article aims to examine how islah or reconciliation was achieved by Nahdlatul Wathan's elites. The conflict of NW in 1998 is a protracted one because the negotiation process of islah failed. Both groups did not find an appropriate point or an ideal format of islah proposal. Through long way process of negotiation, taking more than one decade, finally both group achieved an agreement of islah in May 2010. This article aims to explore the backgrounds and motivations of NW islah between both groups, as well as describe the efforts of undertaken by NW elite for conducting islah during times of conflict. This article also aims to understand what the format of islah has been achieved and how the NW maintain the continuity of islah commitment and agreement. This article is based on ethnographic research undertaken over a period of two years (2008-2010) in East Lombok, West Nusa Tenggara. The collecting and analyzing of data was done using the qualitative method; the collection of data was done using the techniques of participant-observation, in-depth interview, and focus group discussion.
\end{abstract}

Keywords: Islah, Politic, Conflict, Nahdlatul Wathan

\begin{abstract}
ABSTRAK
Artikel ini bertujuan untuk menguji bagaimana islah atau rekonsiliasi dapat tercapai di kalangan elit-elit Nahdlatul Wathan. Konflik NW1998 merupakan salah satu konflik yang berkepanjangn karena proses negosiasi islah selalu kandas di tengah jalan. Kedua kubu belum menemukan titik temu atau format yang tepat mengenai proposal islah NW. Melalui proses negosiasi yang panjang akhirnya pada bulan Mei 2010 kedua kubu NWmencapai kesepakatan untuk islah. Secara khusus artikel ini bertujuan untuk mengeksplorasi bagaimana latar belakang dan motivasi terjadinya islah antara kedua kubu? Bagaimana upaya-upaya islah yang dilakukan selama konflik berlangsung? Selain itu artikel ini juga bertujuan untuk memahami format islah yang telah disepakati dan bagaimana mereka mempertahankan islah tersebut? Artikel ini merupakan hasil penelitian selama dua tahun (2008-2010) di Lombok Timur Nusa Tenggara Barat. Pendekatan yang digunakan dalam penelitian ini adalah etnografi dengan menggunakan metode kualitatif untuk pengambilan dan analisa data. Sedangkan teknik pengambilan data dilakukan melalui observasi-partisipasi, wawancara mendalam, dan fokus diskusi kelompok.
\end{abstract}

Kata Kunci: Islah, Politik, Konflik, Nahdlatul Wathan 


\section{PENGANTAR}

Konflik merupakan salah satu ancaman besar yang dihadapi bangsa Indonesia pada masa Reformasi. Jatuhnya rezim Suharto 1998 ditandai dengan munculnya berbagai konflik komunal hampir di setiap daerah di Indonesia (Anwar et al., 2005; Nugroho et al., 2004). Konflik yang muncul pada masa Reformasi lebih bersifat komunal yang melibatkan sebuah masyarakat, komunitas, organisasi atau institusi sosial (Tomagola, 2006; Colombijn, 2001). Konflik tidak hanya disebabkan oleh perbedaan identitas budaya, bahasa, dan agama, tetapi juga karena adanya kepentingan ekonomi, politik, dan kekuasaan. Anthony Giddens mengatakan bahwa konflik sangat dekat dengan ideologi, politik, dan kekuasaan. Bahkan sebagian besar konflik yang muncul hanya disebabkan oleh faktor kekuasaan (Giddens, 1989: 571). Konflik komunal di Ambon, Maluku, Poso, Kalimantan, dan Lombok memiliki kaitan yang kuat dengan kepentingan politik, ekonomi, dan kekuasaan. Kuatnya pengaruh dari faktor-faktor tersebut menyebabkan konflik terus mengalami polarisasi, reproduksi, dan eskalasi di masyarakat (Van Klinken, 2005: 94, 99; Wilson, 2008: 130131).

Lombok merupakan salah satu daerah rawan konflik sejak rezim Orde Baru turun dari tahta kekuasaan. Dalam satu dekade terakhir telah terjadi berbagai konflik komunal seperti konflik antara kampung, antara agama, dan konflik internal keagamaan yang melibatkan organisasi-organisasi Islam. Konflik agama sangat dominan mewarnai konflik komunal di Lombok seperti konflik antara agama Islam dengan Kristen (2000), konflik internal organisasi Nahdlatul Wathan (1998-2009), konflik antara jamaah Ahmadiyah dengan masyarakat lokal (20022011), konflik kelompok Amphibi dengan komunitas Hindu di Mataram (1999) dan dengan masyarakat di desa Perampauan (2000) di Lombok Barat, dan konflik LDII dengan masyarakat lokal (2002) di Lombok Timur (Kristiansen, 2003: 121-122; Avonius, 2004: 66; Macdougall, 2007: 297; Smith dan Hamdi, 2009: 2).
Artikel ini membahas konflik komunal internal organisasi Nahdlatul Wathan (NW) dan upaya-upaya islah atau rekonsiliasi yang dilakukan oleh kelompok elit. Konflik $N W$ termasuk konflik yang berkepanjangan karena setiap upaya proses negosiasi islah antara agen selalu mengalami kegagalan. $N W$ adalah organisasi sosial keagamaan lokal yang didirikan pada tahun 1953 oleh Tuan Guru Hajji (TGH) Muhammad Zainuddin Abdul Madjid atau lebih dikenal dengan Maulana Syaikh di Pancor, Lombok Timur. Dalam waktu yang tidak lama NW mengalami kemajuan yang sangat pesat dan menjadi kelompok mayoritas Muslim terbesar di Lombok. Jumlah warga NW di Lombok diperkirakan 2 juta orang sehingga ia memiliki peran penting di dalam pembangunan civil society dan pemerintahan (Baharuddin, 2007: 111-115; Rasmianto dan Baharuddin, 2004: 42; Nu'man, 1999: 32).

Sebagai organisasi besar di tingkat lokal NW menghadapi berbagai persoalan baik dari internal maupun eksternal. NW mengalami konflik dan perpecahan setelah pendiri NW Maulana Syaikh wafat tahun 1997. Terdapat dua kubu yang muncul pascaSyaikh yang dipimpin oleh kedua keluarga putrinya yaitu kubu Rauhun (R1) dan Raihanun (R2). Kedua kubu dan pendukungnya bersaing memperebutkan posisi sebagai pemimpin NW yang baru menggantikan Syaikh (Macdougall, 2007: 286). Konflik NW mengalami puncak pada Muktamar NW ke 10 tahun 1998 di Praya, Lombok Tengah. Hasil Muktamar Praya menunjukkan bahwa salah satu kubu terpilih sebagai Ketua Umum Pengurus Besar NW, namun hasil Muktamar ini tidak diterima oleh kubu yang lain yang menilai tidak sah dan melanggar aturan organisasi. Hasil Muktamar melahirkan pro dan kontra di kalangan jamaah $N W$ dan akhirnya berubah menjadi konflik sosial yang berkepanjangan (Saprudin, 2005; Nazri, 2000).

Konflik NW pasca-Muktamar Praya 1998 belum memperlihatkan adanya tandatanda islah antara kedua kubu. Selama satu dekade lebih upaya-upaya islah $N W$ selalu kandas dan gagal di tengah jalan karena 
disebabkan oleh berbagai faktor. Di tengah kebuntuan proses negosiasi islah secara mengejutkan kedua kubu NW mencapai kesepakatan islah pada bulan Mei 2010. Islah NW yang mendadak ini menimbulkan kontraversi di masyarakat karena sarat dengan kepentingan politik elit-elit NW. Islah $N W$ tidak bisa dipisahkan dari proses pencalonan salah satu tokoh NW dari kubu R2 sebagai calon bupati pada Pilkada di Lombok Tengah. Untuk memenangkan Pilkada ini dibutuhkan penyatuan suara $N W$ dari kedua kubu, jika tidak maka sulit bagi calon dari NW untuk meraih kemenangan. Bagaimana proses islah dan motivasi yang melatarbelakanginya akan dibahas berikutnya.

Lombok Timur adalah kabupaten yang paling padat penduduknya di provinsi NTB yakni 1.053.347 jiwa, dengan kategori lakilaki 480.791 jiwa, dan perempuan 572.556 jiwa (BPS Lombok Timur, 2006: 73-91). Lajunya pertumbuhan penduduk di Lombok Timur dan lapangan kerja yang semakin menyempit berdampak pada tingginya jumlah buruh migran (TKI) yang bekerja ke luar negeri seperti di Malaysia dan Arab Saudi. Masyarakat Lombok Timur menganut berbagai macam agama dan aliran kepercayaan seperti Islam, Hindu, dan Kristen. Islam adalah agama mayoritas masyarakat Lombok Timur.

NW didirikan oleh Maulana Syaikh pada tahun 1953 di Pancor, Lombok Timur, dan NTB. Kata NW berasal dari bahasa Arab yakni nahdlah berarti kebangkitan atau pergerakan, dan wathan berarti tanah air, sedangkan Nahdlatul Wathan artinya gerakan tanah air ( $\mathrm{Nu}^{\prime}$ man, 1999: 48). Istilah $N W$ bukan lahir dari Syaikh, tetapi telah dikembangkan oleh Kiai Wahab Hasbullah dan Kiai Mansur sebagai nama organisasi pergerakan di Surabaya tahun 1916 (Noor et al., 2004: 294). Selain NW mereka juga membentuk Nahdlatul Tujjar (NT) dan Nahdlatul Fikri (NF). Fakta sejarah ini menimbulkan pertanyaan, apakah terdapat hubungan antara $N W$ versi Hasbullah dan Mansur dengan NW versi Syaikh. Menurut Muhammad Noor secara organisatoris tidak ada hubungan antara keduanya karena jarak waktu yang cukup jauh, meskipun Syaikh pernah diangkat sebagai konsulat NU di tahun 1950 perwakilan dari pulau Sunda Kecil (Noor et al., 2004: 304).

$N W$ fokus di tiga bidang pembangunan yaitu pendidikan, sosial dan dakwah. Jumlah lembaga pendidikan di bawah naungan NW sebanyak 1.500 buah dari tingkat SD hingga perguruan tinggi (Noor et al., 2004; $\mathrm{Nu}^{\prime}$ man, 1999). Pembangunan lembagalembaga pendidikan ini dilakukan melalui peran kader yang tersebar di berbagai daerah di Lombok. NW juga mendirikan panti asuhan untuk anak yatim dan anak kurang mampu. Mereka disekolahkan dan diberi beasiswa hingga selesai. Untuk kegiatan dakwah para tuan guru NW mengadakan pengajian keliling desa. Pengajian ini dihadiri oleh jamaah $N W$ dari berbagai desa dan sifatnya harian, mingguan, bulanan, dan tahunan. NW mengembangkan tradisi ritual yang dikenal dengan hiziban, wiridan atau zikiran, barzanji, dan syafa'ah. NW juga mengembangkan kesenian dengan menciptakan lagu-lagu berbahasa Arab, Indonesia, dan bahasa Sasak (Noor et al., 2004; $\mathrm{Nu}^{\prime}$ man, 1999; Baharuddin dan Rasmianto, 2004).

NW menganut aqidah Ahlussunnah wa Al-Jama'ah dengan menerapkan mazhab Syafi'i sebagai mazhab tunggal organisasi. Asas organisasi NW adalah Pancasila sesuai dengan undang-udang nomor 8 tahun 1985. Khittah NW adalah tidak berafiliasi kepada salah satu organisasi politik dan organisasi sosial kemasyarakatan mana pun ( $\mathrm{Nu}^{\prime} \mathrm{man}$, 1999; Noor et al., 2004). Dalam praktiknya khittah ini berbeda karena NW sejak berdiri telah aktif di kegiatan politik praktis. Pada Pemilu pertama 1950 pendiri NW aktif di Partai Masyumi dan pernah menduduki jabatan Penasehat Partai Masyumi di tahun 1952. Setelah Masyumi dibubarkan dia ikut membentuk Parmusi bersama tokoh-tokoh dari ormas lain (Noor et al., 2004: 245-246). Sejak Orde Baru muncul NW bergabung dengan Sekertariat Bersama (Sekber) Partai Golkar dan pada tahun 1970 NW secara 
resmi bermitra dengan Partai Golkar (Noor et al., 2004: 257-248).

Perubahan sistem demokrasi dengan multi-partai di Indonesia pasca-Suharto memposisikan NW sebagai organisasi yang sangat diperhitungkan oleh partai politik nasional. Di Era Reformasi, afiliasi politik NW ikut mengalami perpecahan karena kondisi NW yang sedang mengalami konflik internal. Pada Pemilu 1999 kubu R1 bergabung dengan PDR dan kubu R2 memilih tetap bersama Partai Golkar. Pada Pemilu 2004 kedua kubu kembali mengganti bendera partai politiknya, kubu R1 berafiliasi ke Partai Bulan Bintang (PBB), dan kubu R2 berafiliasi ke Partai Bintang Reformasi $(P B R)$. Kedua partai afiliasi NW PBB dan PBR selalu masuk tiga besar dalam perolehan suara di tingkat lokal. Mereka juga berhasil mengantarkan salah satu kadernya sebagai anggota DPR RI. Dikarenakan perolehan kedua partai ini tidak mencapai Parliamentary Threshold (PT) pada Pemilu 2009 di tingkat nasional, maka NW disinyalir akan berganti partai politik. Menurut informasi di lapangan NW kubu R1 akan bergabung ke Demokrat sedangkan R2 bergabung ke Gerindra.

\section{Muktamar Praya: Konflik Tafsir Agama atas Kepemiminan Perempuan}

Konflik sosial yang muncul di masyarakat tidak terjadi secara instan, tetapi hasil dari proses, sejarah, relasi, dan interaksi sosial yang panjang antara agen-agen sosial di masyarakat (Broomley, 2002; Tambiah, 1996; Horowitz, 1985). Konflik NW 1998 merupakan akumulasi dari konflik sebelumnya, puncak dari proses rentetan sejarah panjang yang melibatkan elit-elit NW dalam pertarungan perebutan kekuasaan dan dominasi sumber-sumber modal di dalam dan luar NW (Hamdi, 2011; Hadi, 2010; Saprudin, 2005). Meskipun terlalu jauh mengaitkan hubungan konflik NW 1998 dengan konflik NW 1977 karena konteks yang berbeda, tetapi secara tidak langsung terdapat benang merah yang menghubungkan konflik yang berbeda dekade ini. Fakta di lapangan menunjukkan bahwa sebagian besar aktor yang terlibat konflik 1998 ini adalah aktor-aktor lama yang pernah terlibat konflik 1977. Dengan demikian konflik NW adalah konflik 'warisan' antara keluarga dan kerabat Syaikh yang ingin menguasai seluruh modal ekonomi, non-ekonomi, dan modal simbolik di dalam NW.

Konflik NW terjadi pada masa transisi di tingkat lokal dan nasional. Pendiri NW wafat pada 1997 bersamaan dengan munculnya krisis ekonomi menimpa Indonesia yang berdampak pada reformasi dan transisi politik dari Orde Baru ke Reformasi (Hadi, 2010; Nazri 2001; Hamdi, 2011). Masa transisi ini memiliki pengaruh pada instabilitas sosial-politik di masyarakat termasuk instabilitas di kalangan jamaah NW. Kepergian Syaikh melahirkan pertanyaan siapa yang akan mengganti posisinya sebagai pemimpin $N W$ khususnya dan ummat Islam pada umumnya? Syaikh tidak memiliki anak laki-laki tetapi hanya dua anak perempuan Rauhun (R1) dan Raihanun (R2) yang lahir dari ibu yang berbeda karena dia menganut poligami. Wafatnya Syaikh merupakan sebuah babak baru bagi organisasi dan jamaah $N W$. Selama ini $N W$ selalu identik dengan Syaikh karena selain menjadi pendiri $N W$, dia juga dikenal sebagai pemimpin yang kharismatik yang sangat disegani dan dihormati.

Kepergian tokoh kharismatik NW diikuti dengan munculnya konflik dan perpecahaan terbuka antara keluarga, kerabat, dan elitelit NW. Meskipun konflik keluarga dan elitelit NW ini pada dasarnya telah muncul sejak Syaikh masih hidup, namun bersifat sembunyi-sembunyi karena para aktor konflik merasa sungkan dengan Syaikh yang memiliki kharisma yang kuat. Konflik keluarga Syaikh selain karena persaingan juga karena sikap elit-elit $N W$ yang tidak pernah netral memperlakukan kedua putri Syaikh. Padahal Syaikh di beberapa kesempatan telah berpesan kepada jamaahnya untuk bersikap netral dan tidak membeda-bedakan keduanya. Syaikh mengatakan bahwa kedua putriku adalah ibarat kedua mataku dan siapa yang berpihak kepada salah satu di antara mereka sama artinya dengan me- 
nusuk salah satu mataku. Sikap kelompok elit NW yang diskriminatif sangat mempengaruhi determinasi konflik dan perpecahan yang terjadi di kalangan keluarga Syaikh.

Kekuatiran berbagai pihak akan muncul konflik dan perpecahan terbuka antara kedua kubu NW pasca-wafatnya Syaikh menjadi kenyataan. Konflik NW tidak dapat dihindari dan mengalami puncak pada Muktamar ke-10 di Praya Lombok Tengah 1998 (Nazri, 2001; Hamdi, 2011; Hadi, 2010). Nuansa Muktamar kali ini berbeda dengan Muktamar-muktamar NW sebelumnya. Setidaknya ada tiga hal yang membedakannya, yaitu: (1) muktamar ini tidak diikuti oleh pendiri sekaligus pemimpin kharismatik NW karena dia telah wafat. Biasanya Syaikh selalu hadir di acara Muktamar NW dan memiliki peran dan pengaruh besar untuk menentukan formasi struktur kepengurusan organisasi; (2) muktamar ini sarat dengan kepentingan politik para elit dalam perebutan posisi-posisi penting di dalam kepengurusan organisasi $N W$. Sebagaimana telah disebutkan di atas bahwa ada dua kubu yang muncul bersaing memperebutkan kursi kepemimpinan NW; (3) Muktamar NW diadakan pada masa transisi dari Orde Baru ke Reformasi. Masa transisi dengan turunnya Suharto telah menimbulkan ketidakstabilan sosial-politik di tingkat nasional. Kondisi ini secara tidak langsung berpengaruh terhadap kondisi sosio-politik lokal di Lombok termasuk juga di dalam konteks politik NW.

Muktamar Praya diwarnai persaingan dan pertaruhan gengsi elit-elit NW dari kedua kubu. Menjelang Muktamar mobilisasi massa dan manuver-manuver politik terus dilakukan oleh para elit dalam rangka memenangkan calon mereka. Acara Muktamar berlangsung dari tanggal 24-26 Juli 1998 di lapangan Koni Praya Lombok Tengah. Peserta Muktamar yang berhak memberikan suara pada pemilihan calon ketua umum (Ketum) PB NW sebanyak 92 orang (Hamdi, 2011: 185; Mugni, 2005: 22).

Ada dua tahapan pemilihan calon Ketum yaitu penjaringan bakal calon dan pe- milihan calon Ketum. Seorang bakal calon berhak maju untuk tahap kedua jika memperoleh minimal 18 suara dari 92 suara. Dari hasil tahap pertama penjaringan bakal calon Ketum terdapat dua nama yang muncul yaitu Raihanun dan Ma'sum Ahmad. Raihanun didukung oleh kubu R2 sedangkan Ahmad didukung oleh kubu R1. Raihanun memperoleh 54 suara, dan Ahmad 34 suara, 1 abstain, 1 batal, dan 2 utusan tidak ikut memilih (Hamdi, 2011: 186; Mugni, 2005: 2003). Munculnya nama Raihanun pada bursa bakal calon Ketum tidak pernah diperkirakan sebelumnya oleh kubu R1 karena selama ini dia dikenal sebagai ibu rumah tangga. Kesuksesan Raihanun tidak lepas dari posisinya sebagai putri Syaikh dan juga pengaruh kuat suaminya yang memiliki pengikut yang fanatik ketika memimpin $N W$ bersama Syaikh (Hadi, 2010: 58; Hamdi, 2011: 187).

Selesai penghitungan hasil tahap pertama sidang Muktamar diskor untuk istirahat dan Shalat Jumat. Kubu R1 cukup resah dengan hasil Mutamar apalagi nama yang muncul adalah putri Syaikh yang tentunya sulit untuk dikalahkan. Dia hanya dapat ditandingi oleh kakaknya Rauhun, namun dia terlanjur tidak mencalonkan diri dengan alasan menghindari konflik keluarga. Sidang Muktamar untuk tahap kedua dimulai lagi setelah selesai shalat jumat. Sebelum sidang dimulai Ahmad seorang calon dari kubu R1 mempertanyakan kepada ketua sidang tentang keabsahan status perempuan sebagai pemimpin dalam mazhab Syafi'i.

Menurut penafsiran Ahmad dan kubu R1 bahwa mazhab Syafi'i tidak membolehkan perempuan sebagai pemimpin termasuk pemimpin organisasi, sementara NW hanya menganut mazhab ini. Merespons pertanyaan Ahmad anggota Dewan Syuro PB NW terdiri dari TGH. Ruslan Zain dan TGH. Hilmi Najamuddin mengatakan bahwa tidak ada larangan bagi kaum perempuan sebagai pemimpin di dalam mazhab Syafi'i khususnya pemimpin organisasi. Menurut penafsiran mereka mazhab Syafi'i tidak membolehkan perempuan sebagai pemim- 
pin hanya pada kasus-kasus tertentu seperti menjadi kepala negara, imam shalat bagi laki-laki, dan menjadi hakim pidana (Hadi, 2010: 58; Hamdi, 2011: 188; Saprudin, 2005).

Mendengar respons dari anggota Dewan Syuro PB NW yang notabenenya adalah pendukung R2, Ahmad, dan kubu R1 menyatakan tidak puas. Ahmad mengundurkan diri sebagai salah satu calon Ketum dan menyatakan tidak akan bertanggung jawab dengan hasil Muktamar. Dia dan pendukungnya walk out dari arena Muktamar, sedangkan peserta Muktamar yang lain (mayoritas pendukung R2) tetap melanjutkan agenda pemilihan calon Ketum. Mereka secara aklamasi memilih Raihanun karena Ahmad mengundurkan diri. Raihanun resmi dilantik sebagai Ketum PB NW untuk masa jabatan 1998-2003. Hasil Muktamar Praya melahirkan pro dan kontra di kalangan jamaah $N W$. Kubu R1 menolak hasil Muktamar karena dinilai melanggar aturan organisasi yang menganut mazhab Syafi'i, sedangkan kubu R2 menilai kepengurusan mereka telah sah dan tidak melanggar ajaran mazhab Syafi'I (Hadi, 2010; Hamdi, 2011; Saprudin, 2005; Smith dan Hamdi, 2009). Terjadi konflik tafsir agama tentang kepemimpinan perempuan di kedua kubu yang mengklaim sebagai kelompok mereka yang benar dan kelompok lain yang salah.

Kedua kubu aktif menyosialisasikan hasil Muktamar melalui pengajian di desa-desa yang menjadi basis pendukung mereka. Kedua kubu menggunakan agama sebagai alat legitimasi wacana dan media agama sebagai alat reproduksi wacana dengan melibatkan para tuan guru sebagai agen. Implikasinya konflik dan kekerasan antara jamaah kedua kubu sulit untuk dihindari ketika mereka di dalam satu desa. Kedua kubu berkompetisi memperoleh legitimasi kekuasaan dari masyarakat $N W$. Elit-elit $N W$ tidak hanya memperebutkan massa tetapi juga teritori pengajian yang dinilai penting sebagai bentuk legitimasi. Jika massa mereka lebih besar dari massa kubu yang lain, maka teritori tersebut diklaim sebagai milik mereka dan tidak boleh bagi kubu lain melakukan kegiatan keorganisasian termasuk pengajian di wilayah itu. Keduanya berupaya saling menggagalkan pengajian karena dinilai politis dan merebut teritori kekuasaan mereka. Proses dan mekanisme meluasnya konflik dan kekerasan akan dibahas berikutnya.

\section{PEMBAHASAN Meluasnya Konflik NW: dari Wacana ke Praktik Konflik}

Perang wacana yang terjadi antara elitelit NW dari kedua kubu pasca-Muktamar Praya telah berubah menjadi praktik konflik dan kekerasan antara pendukung mereka. Wacana yang berkembang adalah masing-masing mengklaim sebagai kelompok yang sah dan legitimate dan menyalahkan kelompok yang lain. Proses produksi dan reproduksi wacana dikonstruksi dan direproduksi melalui media agama yaitu pengajian. Wacana agama difungsikan sebagai pendukung dan penguat wacana kekuasaan yang diproduksi oleh kedunya. Apa yang dikatakan dan diwacanakan oleh elit $N W$ menjadi 'kebenaran mutlak' yang diterima begitu saja oleh jamaah NW. Wacana ini ibarat 'sabda' yang mempunyai kekuatan magis yang dapat membentuk dan mempengaruhi perilaku dan tindakan para jamaah (Foucault, 1972: 80; Mills, 1997: 3; Bourdieu, 1977: 80). Mereka akan mengikuti seluruh instruksi elit tanpa bertanya asal-usul, orientasi dan dampaknya terhadap kehidupan mereka. Misalnya ketika mereka diundang ke medan perang untuk bertempur, maka dengan suka rela mereka datang melaksanakan tugas yang diklaim sebagai perang suci.

Praktik konflik dan kekerasan yang dilakukan antara jamaah NW mengalami polarisasi dan reproduksi dari satu tempat ke tempat yang lain. Hijrahnya tokoh dan jamaah NW kubu R2 dari Pancor setelah mendapat tekanan dan serangan kelompok R1 tidak membuat konflik berhenti begitu saja, justru konflik semakin meluas ke desadesa yang menjadi basis jamaah NW (Macdougall, 2007; Hamdi, 2011; Hadi, 2010). 
Apalagi secara organisatoris NW menganut dualisme kepemimpinan setelah kubu R1 mengadakan Muktamar Reformasi pada tahun 1999. Dualisme kepemimpinan di dalam $N W$ memposisikan jamaah pad $a$ pilihan yang sulit dan dilematis karena harus memilih salah satu dari dua kubu NWyang ada (Hamdi, 2011; Smith dan Hamdi, 2009; Hadi, 2010). Meskipun pilihan netral adalah pilihan yang ideal dalam struktur konflik $N W$, tetapi mereka yang memilih posisi ini akan mengalami diskriminasi dan seringkali dicurigai oleh salah satu kubu atau dari kedua kubu NW. Sementara jika memihak salah satu kubu sama artinya melibatkan diri ke dalam konflik. Pilihan yang sulit dan dilematis ini terus menghantui jamaah $N W$ selama satu dekade sampai lahirnya konsesus untuk islah.

Kekerasan antara jamaah NW lebih banyak terjadi di Lombok Timur daripada di Lombok Tengah dan Barat. Meskipun demikian konflik dan kekerasan ini melibatkan hampir seluruh jamaah di Lombok. Perang $N W$ bukan hanya perang antara warga $N W$ tetapi perang antara pepadu atau orang sakti yang saling menguji tingkat kesaktian ilmu mereka (Hamdi, 2011: 240: Smith dan Hamdi, 2009). Para pepadu memanfaatkan konflik NW sebagai ajang pembuktian tingkat kesaktian mereka. Sementara di satu sisi kedua kubu saling mengundangkan pepadu dari desa-desa lain untuk memperkuat pertahanan dan serangan mereka.

Menurut informasi di lapangan, perang 'atas' lebih dahsyat daripada perang 'bawah'. Yang dimaksud dengan istilah perang 'atas' adalah perang di udara yang melibatkan orang-orang sakti yang berkelahi dengan cara terbang dan biasanya dilakukan pada malam hari. Sedangkan perang 'bawah' adalah perang di darat yang melibatkan masyarakat secara umum dan biasanya pada siang hari (Hamdi, 2011: 241). Perang 'atas' hanya melibatkan orang-orang yang mempunyai ilmu kesaktian tinggi yang bisa mengubah dirinya ke berbagai jenis binatang. Tidak ada data pasti yang menyebutkan berapa jumlah orang yang meninggal dalam perang 'atas' ini.
Wilayah-wilayah yang rawan konflik dan kekerasan adalah kecamatan Suralaga, Selong, Masbagik, Kota Raja, Wanasaba, Peringgasela, Peringgabaya, Suka Mulia, dan Aikmel. Konflik mengalami ekstrimasi jika terdapat elit-elit NW terutama Tuan Guru dari kedua kubu di dalam satu desa. Konflik dan kekerasan tidak bisa dihindari karena para Tuan Guru saling berebut simpati massa dan ingin menunjukkan kekuatan kubu masing-masing di desa tersebut. Kerusuhan pertama terjadi di Pancor 1998 ketika pendukung R1 menyerang tokoh dari kubu R2 (Mugni, 2005: 32; Nazri, 2001: 14; Hamdi, 2011: 242).

Pendukung kedua kubu terus saling meneror dan melakukan tindak kekerasan. Kubu R1 lebih diuntungkan karena mayoritas masyarakat Pancor adalah pendukung mereka. Rumah dan toko-toko milik tokoh R2 dijadikan sasaran serangan oleh pendukung R1 yang kecewa dengan sikap mereka yang tidak netral dengan putri Syaikh. Di antara Tuan Guru yang menjadi target serangan adalah TGH. Anas Hasyri, TGH. Mahmud Yasin, dan TGH. Tahir. Serangan demi serangan terus dilakukan oleh pendukung R1 yang berakhir dengan hijrahnya kubu R2 dan pendukungnya dari Pancor ke desa Kalijaga kemudian ke desa Anjani.

Peristiwa di Pancor hanya merupakan babak awal terjadinya konflik dan kekerasan antara jamaah NW. Perang terbuka terus meluas ke wilayah-wilayah lain di Lombok Timur setelah kubu R2 meninggalkan Pancor dan membangun kekuatan di desa Kalijaga dan Anjani. Pada tahun 2000 terjadi kerusuhan antara kedua pendukung di desa Gotong Royong ketika pengajian kubu R1 berusaha digagalkan oleh kubu R2. Tidak ada korban jiwa dalam peristiwa ini, hanya beberapa orang terluka (Hamdi, 2000: 251; Mugni, 2005; Nazri, 2001).

Di tahun yang sama 2000 juga terjadi kerusuhan di Desa Kesik, Kecamatan Masbagik ketika kedua jamaah NW saling menghadang dan menggagalkan pengajian. Kerusuhan ini menyebabkan puluhan orang terluka akibat saling melempar dengan batu dan senjata tajam (Hamdi, 2011: 255-256). 
Sepanjang tahun 2000-2001 terjadi aksi saling serang di beberapa desa sehingga menimbulkan kerusakan rumah seperti di desa Kelayu, dusun Majuet, dan Kota Raja (Ibid, 268). Pada tahun 2002 terjadi perang besar antara kedua pendukung di desa Wanasaba. Kubu R2 mengadakan pengajian, tetapi digagalkan oleh kubu R1 sebagai aksi balasan atas serangan pengajian sebelumnya. Menurut catatan kepolisian 4 orang meninggal dunia dan puluhan orang terluka (Ibid, 272).

Kerusuhan Wanasaba merembet ke desa-desa yang lain termasuk desa Paok Lombok, Borok Tumbuh dan desa Tebaban. Korban dalam kerusuhan di desa-desa tersebut adalah 4 orang meninggal dunia, ratusan rumah dibakar dan dirusak, dan ratusan orang mengungsi ke desa lain. Kerusuhan di Paok Lombok disebabkan keinginan tokoh dari kubu R2 untuk mengadakan acara Maulid di masjid, tetapi tidak diberi izin oleh tokoh-tokoh R1 sehingga massa dari kedua kubu bentrok. Kerusuhan ini melibatkan desa-desa tetangga seperti Dusun Majuet, Dusun Borok Tumbuh dan Desa Tebaban.

Melihat pola konflik dan kekerasan antara jamaah NW di atas secara keseluruhan hampir sama yaitu terjadi pada waktu pengajian dan motivasinya adalah perebutan massa dan pengaruh di kalangan jamaah NW sebagai bagian dari legitimasi kekuasaan kedua kubu. Masing-masing kubu membutuhkan pengakuan sebagai kubu yang sah memimpin organisasi NW. Media agama seperti pengajian dijadikan sebagai alat reproduksi kekuasaan dan sekaligus kekerasan. Setiap ada pengajian maka kekerasan juga muncul di pengajian tersebut. Pengajian bukan lagi berfungsi sebagai tempat siraman rohani, tetapi lebih sebagai tempat saling memfitnah, menjatuhkan, menyerang dan sebagai tempat aksi kekerasan. Salah satu kubu berupaya menggagalkan pengajian dari kubu yang lain karena dinilai politis dan dapat mempengaruhi massa dari kubu mereka. Ada kekuatiran jika nantinya pendukung mereka akan beralih ke kubu yang lain. Pola-pola konflik di dalam pengajian ini terus mengalami reproduksi dan terinternalisasi di dalam diri jamaah $N W$.

\section{Upaya-Upaya Islah yang Selalu Gagal}

Islah atau rekonsiliasi merupakan salah satu tahapan penting dalam proses resolusi konflik $N W$. Islah mengarah pada restorasi dan rekonstruksi struktur yang mengalami kekacauan sosial (disorder) dan instabilitas akibat konflik dan kekerasan yang berkepanjangan. Islah identik dengan proses penyembuhan (healing) luka dan trauma masyarakat yang menjadi korban, mencari keadilan (justice) dan kebenaran (truth) dan saling memaafkan (forgiveness) antara korban dan pelaku kekerasan (Skaar dan Bloomfield, 2008: 14). Islah tidak hanya merupakan sebuah tujuan yang harus dicapai, tetapi juga merupakan sebuah proses yang harus dijalani dan dilakukan oleh para pelaku dan korban konflik (Bloomfield et al., 2006: 11). Tujuan islah adalah membangun kembali kehidupan bersama antara pelaku dan korban konflik, tidak harus mencintai mereka, atau memaafkan mereka, atau melupakan masa lalu, tetapi co-exist untuk mengembangkan tingkat kerja sama membagi kehidupan sosial kemasyarakatan (Ibid, 2006: 11).

Proses islah atau rekonsiliasi bukanlah sesuatu yang mudah untuk direalisasikan. Pada kasus-kasus tertentu terkadang islah mengalami keberhasilan, dan terkadang juga banyak mengalami kegagalan total. Menurut David Bloomfield islah harus dilihat sebagai proses yang panjang yang membutuhkan beberapa dekade bahkan pergantian beberapa generasi (Bloomfield, 2006: 22). Konflik di Aceh, Ambon, Poso, TimorTimur, Kalimantan, dan Lombok membutuhkan waktu puluhan tahun untuk mencapai rekonsiliasi. Konflik NW termasuk salah satu konflik yang berkepanjangan di Indonesia dan untuk sementara waktu dapat dikatakan gagal dalam mencapai islah. Konflik NW yang telah menginjak satu dekade lebih belum memperlihatkan tandatanda akan terjadinya islah atau rekonsiliasi terutama di tingkat elit. Sejak 1998-2009 
proses islah belum mengalami kemajuan yang berarti, bahkan setiap adanya inisiasi dan upaya islah selalu kandas di tengah jalan (Hamdi, 2010: 353). Kedua kubu belum menemukan titik temu dan format islah yang tepat karena adanya sarat dan tuntutan yang tidak mungkin terpenuhi oleh salah satu kubu.

Peran pemerintah daerah sebagai pihak yang seharusnya netral dan mampu memfasilitasi proses islah NWikut terjebak dalam konflik. Kecenderungan yang terjadi adalah mereka memihak salah satu kubu sehingga menimbulkan perlawanan dari kubu NW yang lain. Misalnya mantan Bupati Lombok Timur M. Sahdan dinilai lebih condong ke kubu R1, sementara mantan bupati setelahnya Ali Bin Dahlan cenderung ke kubu R2. Sulit bagi pemerintah daerah bersikap netral karena kepentingan yang besar terhadap $N W$. Bahkan pemerintah seringkali memamfaatkan konflik $N W$ untuk tujuan politik praktis. Mereka tidak mau melihat NW bersatu, jika bersatu, maka NW akan menjadi rivalitas politik yang sangat kuat melihat kekuatan NW sebagai kelompok majoritas di Lombok. Terbukti pada Pilkada 2008 NW dari kubu R1 berhasil mengantarkan kader terbaiknya sebagai gubernur NTB dan Bupati Lombok Timur. Kemenangan ini diraih tanpa dukungan kubu R2 yang justru mendukung calon lain di luar NW.

Kegagalan islah di tingkat elit pada kenyataannya tidak berlaku bagi jamaah $N W$. Di beberapa desa yang sebelumnya sangat rawan dan parah akibat konflik mulai membangun kembali kehidupan mereka (Hamdi, 2011: 343-344). Sebagian besar masyarakat di desa itu berupaya melakukan islah secara natural tanpa tekanan atau arahan dari kelompok elit. Mereka mulai sadar dengan apa yang menimpa mereka dan keluarga yang terpecah belah akibat konflik. Mereka mulai saling menegur dan mengundang kembali keluarga mereka yang berbeda afiliasi ke- $N W$-annya. Ikatan komunalitas dan kekeluargaan yang hancur akibat terjangan badai konflik seakan menemukan kembali eksistensi dan fungsinya di masya- rakat. Hambatan utama islah NW hanya pada kelompok elit. Mereka masih berupaya mempertahankan konflik untuk menjaga kepentingan mereka dan kelompoknya tanpa mempedulikan keadaan masyarakat (Ibid, 354).

Setidaknya terdapat empat faktor yang menyebabkan kegagalan islah NW yaitu, (1) faktor kepentingan, (2) gengsi, (3) lemahnya budaya dialog, dan (4) faktor wasiat Maulana Syaikh. Faktor kepentingan telah menghambat proses islah NW. Kepentingan di sini tidak hanya kepentingan politik, tetapi juga kepentingan ekomomi, status, pengaruh dan pengakuan sosial. Selain itu, faktor gengsi juga menjadi penghambat proses islah karena kedua kubu merasa lebih mampu, legitimate, dan lebih besar sehingga merasa gensi menerima kehadiran kubu lain. Budaya dialog yang tidak berkembang di lingkungan NW juga menjadi faktor kendala islah karena para elit tidak pernah bertemu dan berdialog untuk mencari titik temu masalah yang mereka hadapi. Para elit sangat alergi dengan dialog, mereka hanya berani saling mengkritisi di balik layar. Sementara wasiat Maulana Syaikh yang memprediksi perpecahan NW yang akan berlangsung 20 tahun telah diyakini kebenarannya sehingga sebesar apa pun usaha untuk islah tidak akan berhasil kecuali menunggu apa yang dikatakan dalam wasiat tersebut. Kalau dihitung dari sejak konflik NW 1998, maka islah NW akan terwujud pada tahun 2018.

\section{Islah NW: antara Kepentingan Politik atau Kepentingan Ummat}

Di tengah kebuntuan para elit NW dalam upaya mewujudkan islah, sebuah 'keajaiban' datang pada Mei 2010, kedua kubu NW akhirnya sepakat untuk islah. Kesepakatan islah ini menimbulkan kontroversi di masyarakat karena prosesnya dinilai instan dan motivasinya sarat dengan kepentingan politik. Kubu R2 secara tiba-tiba menerima tawaran islah dari kubu R1, padahal sebelumnya berbagai langkah dan pendekatan telah dilakukan namun tidak pernah berhasil. Islah NW dalam konteks 
sekarang ini sulit untuk dipisahkan dari realitas dan dinamika politik lokal ketika salah seorang putra Raihanun Gede Sakti dicalonkan oleh kubu R2 sebagai calon bupati Lombok Tengah priode 2010-2015.

Pencalonan Sakti didukung oleh partai politik afiliasi NW Partai Bintang Reformasi $(P B R)$ yang berkoalisi dengan Partai Demokrat. Untuk memenangkan Pilkada Sakti membutuhkan dukungan seluruh suara dari jamaah $N W$ baik dari kubu ibunya R2 maupun dari kubu bibiknya R1. Sulit bagi Sakti menggapai kemenangan jika suara NW terpecah dan terbagi-bagi ke calon lain. Melihat momentum politik inilah elit-elit kubu R1 menawarkan kerja sama mendukung pecalonan Sakti dengan sarat NWharus bersatu.

Tawaran islah dari kubu R1 adalah pilihan yang mendekati mustahil bagi R2 karena selama ini mereka tidak mengakui kepengurusan NW versi R1. Bahkan satu-satunya sarat yang diberikan oleh R2 adalah pembubaran kepengurusan R1 dan mengakui kubu R2 sebagai kelompok yang sah hasil Muktamar Praya. Dikarenakan tidak ada pilihan lain bagi kubu R2 yang mencalonkan Sakti, mereka akhirnya menerima tawaran islah tersebut. Langkah politik R2 yang menerima tawaran islah R1 menimbulkan pertanyaan di tengah-tengah masyarakat tentang keseriusan mereka dalam melakukan islah. Muncul kesan jika islah $N W$ bersifat semu atau sementara disebabkan oleh kepentingan politik yang mendasarinya. Masyarakat kuatir islah NW terancam gagal apabila agenda politik mereka tidak tercapai dalam konteks ini Sakti mengalami kegagalan pada Pilkada. Elit-elit R2 mengemukakan proposal islah khususnya islah keorganisasian dapat terwujud jika Sakti memenangkan Pilkada, sebaliknya jika dia gagal dalam Pilkada maka islah organisasi sulit terwujud dan hanya bersifat islah keluarga. Sementara kubu R1 menginginkan islah secara total termasuk islah organisasi yakni penyatuan kepengurusan dalam satu komando.
Terdapat dua hal yang mendasari terjadinya islah $N W$ terlepas dari asumsi dan opini yang berkembang di masyarakat yaitu: pertama, adanya kerinduan antara keluarga Syaikh untuk bertemu. Setajam apapun konflik dan perpecahan di kalangan pemimpin $N W$, mereka masih memiliki hubungan persaudaraan. Keluarga Syaikh tidak pernah bertemu lebih dari satu dekade (1998-2009) sejak muncul konflik dan kekerasan secara terbuka antara pendukung mereka. Selama konflik kedua keluarga Syaikh saling serang melalui mimbar-mimbar keagamaan seperti pengajian. Konflik NW seperti virus ganas yang masuk ke semua sendi kehidupan jamaah NW.

Kedua, adanya kepentingan politik elitelit NW terkait Pilkada Lombok Tengah. Kepentingan politik sangat dominan dalam islah ini, seandainya bukan karena kepentingan politik kenapa islah tidak dilakukan sebelumnya. Padahal jamaah NW secara umum telah lama menginginkan islah. Keinginan masyarakat bawah ini tidak pernah dihiraukan oleh sebagian elit-elit NW. Mereka berusaha mempertahankan konflik demi menjaga kekuasaan mereka di semua ranah.

Islah NW diikuti dengan bertemunya elit-elit NW dari kedua kubu. Setelah difasilitasi oleh elit-elit NW akhirnya kedua putri Syaikh Rauhun dan Raihanun bertemu untuk pertama kalinya setelah berpisah selama 12 tahun. Pada tanggal 2 Mei 2010 mereka bertemu di makam Maulana Syaikh di Pancor, Lombok Timur. Keduanya didampingi oleh putra mereka dan sebagian elit NW yang menggagas islah ini. Pertemuan keluarga besar Syaikh ini sangat spesial dan mengharukan semua pihak karena sebelumnya betapa sulit mempertemukan mereka dalam satu ruang. Ucapan takbir 'Allahu akbar' dengan suara gemuruh oleh para jamaah dan elit-elit $N W$ mengawali pertemuan keduanya. Mereka melakukan doa bersama yang dipimpin oleh TGB. Zainul Majdi. Selesai berdoa mereka selanjutnya berkunjung ke rumah R1 yang tidak jauh dari area makam. 
Sepanjang pertemuan islah tersebut Raihanun terlihat kurang nyaman karena kehadiran media massa. Dia tidak menginginkan wartawan datang meliput karena pertemuan ini dinilai sebagai pertemuan awal keluarga. Dia menutupi wajahnya dengan kerudung dan berusaha menghindari pengambilan gambar, namun usahanya gagal karena para wartawan tidak berhenti mendokumentasikan foto mereka berdua. Setelah acara doa di ruang tamu di rumah R1 seluruh keluarga Syaikh masuk ke dalam ruangan dan tidak diperbolehkan seorang wartawan meliput acara inti keluarga. Hanya seorang petugas pengambil foto dari $N W$ yang dipercaya menemani mereka sehingga semua pembicaraan dapat direkam.

Mereka sangat antusias dan bahagia dapat berbicara, menuangkan rasa rindu yang selama ini terpendam akibat konflik yang panjang. Mereka berfoto bersama sebagai bukti bahwa $N W$ telah menyatu dan tidak ada lagi persoalan di antara mereka. Foto ini kemudian diabadikan dalam bentuk baleho besar yang dipajang di pinggir jalan di depan kantor PB NW Pancor. Selain bercerita tentang keluarga mereka juga membicarakan situasi politik kaitannya dengan pencalonan Gede Sakti dan langkahlangkah politik yang dilakukan oleh tim suksesnya.

Sebelum pertemuan kedua tokoh kunci NW di atas terlebih dahulu diadakan pertemuan oleh kedua putra mereka yang diwakili oleh Syamsul Lutfi (wakil Bupati Lombok Timur) dan Sakti pada acara tablig akbar sekaligus kampanye politik di Praya Lombok Tengah. Para tuan guru, politisi, dan jamaah NW dari kedua kubu untuk pertama kalinya kumpul bersama-sama di acara pengajian tablig akbar ini. Lutfi dalam ceramahnya mengatakan: "dulu konflik dan perpecahan NW terjadi di Praya Lombok Tengah ketika NW mengadakan Muktamar ke 10 di tahun 1998, maka sekarang islah NW juga dimulai dari Praya Lombok Tengah."

Pidato Lutfi disambut tepuk tangan meriah oleh jamaah $N W$. Lutfi juga mengata- kan bahwa tolong acara silaturrahmi dan islah ini disebarluaskan kepada seluruh jamaah NW yang belum mengetahui supaya tidak ada lagi sesuatu yang tidak diinginkan. Sakti dari kubu R2 juga memberikan sambutan dengan menekankan pentingnya jamaah $N W$ untuk bersatu, merapatkan barisan, dan melanjutkan perjuangan Syaikh. Dia mengatakan untuk mengakhiri konflik yang berkepanjangan, maka biarlah untuk urusan orang tua dengan orang tua, sedangkan urusan anak diselesaikan dengan anakanak.

Untuk mensosialisasikan islah ini kedua kubu mengadakan pawai keliling Lombok. Pawai ini melibatkan seluruh elemen masyarakat NW seperti siswa, guru, mahasiswa, dosen, politisi, serta jajaran pengurus $N W$. Pawai ini bertujuan supaya masyarakat umum mengetahui adanya islah $N W$ dan tidak ada lagi keraguan yang menimbulkan pro dan kontra di tengah masyarakat. Fakta di lapangan menunjukkan bahwa tidak semua jamaah dan elit-elit NW setuju dengan islah, sebagian menolak dan tidak mempercayai dan mengakui islah $N W$. Apalagi kubu R2 tidak pernah secara terbuka dan transparan mengumumkan islah di depan jama'ahnya. Selain pawai islah kedua elit NW juga mengadakan acara ritual keagamaan bersama-sama seperti mengadakan pengajian dan membaca hizib NW. Kedua putri Syaikh juga diundang untuk hadir pada kampanye politik Sakti. Kehadiran mereka diharapkan mampu menarik perhatian dan simpati masyarakat supaya mendukung Sakti dan menunjukkan jika NW benar-benar islah.

Terlepas dari pro dan kontra mengenai kebenaran dan keikhlasan islah oleh kedua kubu NW ini, tetapi islah ini telah memberikan dampak yang sangat positif bagi masyarakat Lombok khususnya jamaah NW. Islah ini telah melebur sekat-sekat yang selama ini menjadi jurang pemisah antara kubu R1 dan R2. Islah juga secara tidak langsung mengurangi tekanan bagi jamaah NW sebagai orang yang selalu 'dicurigai' memihak ke salah satu kubu. Sedangkan secara poli- 
tik islah NW telah mendongkrak perolehan suara Sakti dengan memenangkan Pilkada pada putaran pertama. Sakti berhasil memenangkan Pilkada pada putaran pertama dengan memperoleh $24,71 \%$ suara yang disusul oleh pasangan Maik-Meres 21,83\%, Jari 19,94\%, dan Suke 19,33\%. Meskipun diurutan pertama Sakti harus bertarung pada putaran kedua karena tidak ada pasangan yang memperoleh lebih dari 50\% lebih dari jumlah total suara.

Walaupun Sakti telah memenangkan putaran pertama, namun belum ada jaminan jika dia mampu memenangkan putaran kedua karena jarak suara yang diperoleh tidak jauh berbeda dengan rival politiknya. Putaran kedua juga menjadi pertaruhan terakhir atas paket islah NW. Jika gagal, maka islah NW secara organisasi akan terancam gagal. Pil pahit harus ditelan oleh calon $N W$ karena pada putaran kedua Sakti kalah dari pasangan Maik-Meres. Sakti yang diprediksi memenangkan Pilkada menurut hasil survey LSI mengalami kekalahan cukup besar dengan perolehan suara $40 \%$, sedangkan lawan politiknya Maik-Meres 59,3\%.

Kekalahan ini mencoreng reputasi dan legitimasi politik NW karena sebelumnya tokoh NW dari kubu R1 berhasil memenangkan dua jabatan penting yaitu gubernur NTB dan Bupati Lombok Timur pada Pilkada 2008. Selain itu kekalahan ini juga berdampak pada proses islah yang telah berlangsung dan hubungan kedua keluarga Syaikh. Hingga sekarang islah dalam konteks organisasi tidak terwujud, bahkan tidak ada upaya pembicaraan kembali mengenai islah oleh elit-elit $N W$. Kedua kubu masih berjalan seperti sebelumnya mengelola organisasi masing-masing.

\section{SIMPULAN}

Proses negosiasi islah NW mengalami jalan buntu sejak pecahnya konflik dan kekerasan antara kedua kubu 1998-2009. Selama konflik pintu negosiasi islah sepertinya sudah tertutup, kedua kubu berjalan dengan sendiri-sendiri dan tidak mau menerima mediasi islah baik dari internal elit-elit $N W$ maupun eksternal pemerintah daerah.
Ruang-ruang konflik yang semakin melebar ke ranah-ranah yang lain tidak hanya di $N W$ tetapi juga di ranah politik praktis, ikut mempersempit ruang dan prospek islah ke depan. Sementara islah NW membutuhkan pengorbanan yang cukup besar khususnya kepentingan-kepentingan dari kelompok elit. Kalau mereka tidak mau mengorbankan kepentingan pribadi dan kelompoknya, maka islah NW tidak mungkin dapat terwujud.

Pro dan kontra islah NW di tahun 2010 merupakan sesuatu yang wajar karena masyarakat dan jamaah NW telah lama menunggu pencapain islah tersebut. Selama ini negosiasi islah hanya bersifat wacana tanpa aksi dan realisasi sehingga melahirkan rasa skeptis dari masyarakat. Jamaah $N W$ mengaku pasrah dengan proses negosiasi islah dan menyerahkan semuanya kepada kedua pemimpin NW. Tidak ada angin dan badai tiba-tiba kedua kubu mensosialisasikan kesepakatan islah yang sarat dengan motivasi kepentingan politik di samping kepentingan ummat. Ranah politik di ambil sebagai media untuk islah karena ranah-ranah yang lain tidak dapat diterima dan tidak marketable bagi kedua kubu. Langkah islah dengan jalan politik mengindikasikan kalau faktor kekuasaan sangat dominan, di dalam konflik NW selain faktor ekonomi dan keluarga. Ketika faktor kekuasaan atau politik yang dominan, maka jalan islah yang ditempuh harus melalui jalur politik atau sharing kekuasaan.

Apa yang dilakukan oleh elit-elit NW untuk merekonstruksi proses islah di jalur politik sudah tepat. Elit-elit NW tidak memiliki banyak pilihan pendekatan untuk islah. Saya berpendapat bahwa konflik NW harus diselesaikan melalui jalur politik dan sharing kekuasaan karena dominasi faktor itu terhadap konflik NW. Masyarakat tidak terlalu peduli dengan strategi dan pendekatan yang dilakukan untuk islah, yang penting islah dapat dilaksanankan secara berkelanjutan. Pilihan transaksi politik sebagai jaminan islah NW bukan tanpa risiko, seandainya Sakti gagal kemungkinan besar islah NW akan mengalami kegagalan. kekuatiran banyak pihak atas langkah elit- 
elit NW dengan menyandera islah dalan transaksi politik memperlihatkan tanda-tanda kebenaran. Hingga sekarang belum ada lagi upaya islah NW secara organisasi pasca kakalah Sakti pada putaran kedua Pilkada Lombok Tengah. Padahal elit-elit NW dari kedua kubu telah berkomitmen untuk menyatukan kepengurusan $N W$ dalam satu komando.

Sebagian elit-elit yang tidak setuju dengan islah NW membuat dalih, jika islah $N W$ sekarang ini hanya pada tataran keluarga, bukan pada tataran organisasi. Sementara organisasi NW tidak bisa dipisahkan dengan keluarga Syaikh. Ketika kedua putri Syaikh (Rauhun dan Raihanun) sudah islah, maka semua lapisan di bawahnya harus ikut islah. Namun fakta di lapangan sangat berbeda karena elit-elit di bawahnya menilai apa yang mereka lakukan adalah bagian dari islah NW dalam konteks keluarga bukan organisasi. Dengan demikian islah NW belum tuntas dan konflik NW akan menjadi bom waktu yang akan siap meledak setiap saat. Momentum-momentum politik akan menguji kembali apakah $N W$ akan islah secara organisasi atau sebaliknya tetap mempertahankan konflik. Gesekan massa sangat dikuatirkan terjadi kembali seandainya islah secara organisasi tidak segera direalisasikan.

Ada tiga hal yang perlu dilakukan oleh elit-elit NW dalam rangka melanjutkan proses islah organisasi. Pertama, pemimpin kedua kubu NW segera melakukan Muktamar islah untuk memilih pemimpin NW yang baru yang lebih legitimate dan bersih dari sejarah konflik. Muktamar islah ini penting dilakukan dalam rangka memutus mata rantai konflik dan pro-kontra terhadap kepengurusan NW sebelumnya. Seperti yang dijelaskan di atas bahwa kepengurusan NW di kedua kubu sekarang ini adalah produk konflik.

Kedua, calon pemimpin NW yang baru harus mampu mengakomodasi kepentingan kedua kubu NW secara berimbang dan adil sehingga tidak memunculkan resistensi dari salah satu kubu. Formasi kepengurusan harus diisi dengan jumlah yang sama dari kedua kubu. Dengan demikian tidak ada kubu yang dominan terhadap kubu yang lain.

Ketiga, melakukan modernisasi $N W$ di semua bidang termasuk sistem kepengurusan, rekruktmen dan adminsitrasi organisasi. Dengan modernisasi organisasi ini diharapkan dapat meminimalisasi potensi konflik di kalangan elit-elit NW akibat penyimpangan aturan organisasi.

\section{DAFTAR PUSTAKA}

Anwar, D.F., Bouvier, Helen, Smith, Glenn dan Tol, Roben (eds.), 2005, Konflik Kekerasan Internal: Tinjauan Sejarah, Ekonomi, Politik dan Kebijakan di Asia Pasifik, Jakarta: Kerjasama Yasasan Obor Indonesia, LIPI, Lasema-CNRS, KITLV.

Avonius, L, 2004, Reforming Wetu Telu: Islam, Adat and the Promises of Re-gionalism in Post-New Order Lombok, Yliopistopaino: Helsinki.

Baharuddin, 2007, Nahdlatul Wathan $\mathcal{E}$ Per-ubahan Sosial, Yogyakarta: Genta Press.

Baharuddin dan Rasmianto, 2004, Maulana Lentera Kehidupan Umat, Malang: Mintra Insan Cendekia.

Bloomfield, David, Barnes, Teresa and Huyse, Luck, 2006, Reconciliation After Violent Conflict: A Handbook, Stockholm: IDEA.

Bourdieu, P, 1977, Outline of a Theory of Practice, Cambridge, UK: Cambridge University Press.

BPS Lombok Timur, 2006, Lombok Timur dalam Angka, Lombok Timur: BPS.

Bromley, D.G., dan Melton, J.G. (Eds.), 2002, Cults, Religion and Violence, Cambridge, UK: Cambridge University Press.

Colombijn, F, 2001, "What is so Indonesian about Violence", Dalam Wessel, Ingrid and Georgia, Wimhofer, Violence 
in Indonesia, Hamburg: Hem. Abera Press.

Foucault, M., 1972, The Archeology of Knowledge, New York: Pantheon Books.

Giddens, A., I989, Sociology, Oxford: Polity Press.

Hadi, A., 2010, Charismatic Leadership and Traditional Islam in Lombok: History and Conflict in Nahdlatul Wathan, Thesis: MA Program of the School of Culture, History and Languages, The Australian National University.

Hamdi, S., 2011, Reproduksi Konflik dan Kekuasaan dalam Organisasi Nahdlatul Wathan (NW) di Lombok Timur Nusa Tenggara Barat, Belum Diterbitkan, Disertasi: Program Studi Agama dan Lintas Budaya, Pascasarjana Universitas Gadjah Mada.

Horowitz, D.L., 1985, Ethnicity Group in Conflict, Los Angles: University of Berkeley Press.

Kristiansen, S., 2003, “Violent Youth Groups in Indonesia: The Cases of Yogyakarta and Nusa Tenggara Barat," Sojourn, vol. 18, pp.110-138.

Macdougall, 2007, "Criminality and the Political Economy of Security in Lombok" dalam Renegotiating Boundaries: Local Politics in Post-Suharto Indonesia, Leiden: KITLV Press.

Mills, S., 1997, Discourse, London and New York: Routledge.

Mugni, 2005, Nahdlatul Wathan Pasca Maulana Syaikh, Draf buku yang belum diterbitkan.

Nazri, 2001, Membedah Konflik Rauhun-Raehanun, Pancor: Penerbit Kita.

Noor, M., et al., 2004, Visi Kebangsaan Religius: Refleksi Pemikiran dan Perjuangan Tuan Guru Kyai Haji Muhammad Zainuddin Abdul Madjid 1904-1997, Ciputat: PT. Logos Wacana Ilmu bek- erjasama dengan Pondok Pesantren Nahdlatul Wathan Jakarta.

Nugroho, Fera, Dirdjosanjoto, Pradjarto, Kana, Nico L., 2004, Konflik dan Kekerasan Pada Aras Lokal, Yogyakarta: Pustaka Percik \& Pustaka Pelajar.

Nu'man, H., 1999, Maulana Syaikh TGKH. Muhammad Zainuddin Abdul Madjid: Riwayat Hidup dan Perjuangannya, Mataram: Pengurus Besar Nahdlatul Wathan.

Saprudin, 2005, Konflik Kekuasaan di Tubuh Organisasi Nahdlatul Wathan Antara Kubu Hajjah Siti Rauhun dengan Kubu Hajjah Siti Raihanun, Belum diterbitkan, Tesis: Program Master Jurusan Sosiologi, Universitas Gadjah Mada.

Smith, Bianca J. dan Hamdi, S., 2009, “The Politics of Female Leadership in Nahdlatul Wathan Pesantren, Lombok, Eastern Indonesia" dalam International Journal of Pesantren Studies, Vo-1.3, No. 1, pp 1-25.

Tambiah, S. J., 1996, Leveling Crods: Ethnonationalist Conflict and Collective Violence in Sout Asia, Berkeley, London dan Los Angles: University of California Press.

Tomagola, T. A., 2006, Republik Kapling, Yogyakarta: Resist Book.

Van Klinken, G., 2005, “Pelaku Baru, Identitas Baru: Kekerasan antar Suku pada Masa Pasca Suharto", dalam Anwar et al., (ed), Konflik Kekerasan Internal: Tinjauan Sejarah, Ekonomi, Politik dan Kebijakan di Asia Pasifik, Jakarta: Kerjasama Yasasan Obor Indonesia, LIPI, Lasema-CNRS, KITLV.

Wilson, Chris, 2008, Ethno-Religious Violence in Indonesia: From Soil to God, USA and Canada: Routledge. 